\title{
Reflections on Operational Competencies Required of Educators at Public Secondary Schools
}

\author{
Janet Chalmers ${ }^{1}$ \\ Jhalukpreya Surujlal ${ }^{2}$ \\ Manilall Dhurup ${ }^{3}$
}

\author{
1 Vaal University of Technology, Vanderbijlpark, Gauteng, South Africa \\ 2North-West University, Vanderbijlpark, Gauteng, South Africa Babs.Surujla@nwu.ac.za \\ 3 Vaal University of Technology, Vanderbij|park, Gauteng, South Africa
}

\section{Doi:10.5901/mjss.2013.v4n2p181}

\section{Abstract:}

The primary objective of this study was to identify the operational competencies perceived by educators to be important in teaching at secondary schools. The secondary objective was to investigate the relationship between secondary school educators' overall teaching satisfaction and the identified competencies. The results of the survey indicated that the competency factors that educators perceived to be of importance were: communication and behaviour management, interpersonal relationships, planning and assessment, leadership skills, and perseverance and organisational commitment. The level of correlation of these identified factors with teaching satisfaction was also assessed- indicating that interpersonal relationships had the highest correlation with teaching satisfaction and factors like planning and assessment, organisational commitment and communication and behaviour management had a moderate influence on teaching satisfaction.

Keywords: competency; operational competencies; educators; teaching satisfaction

\section{Introduction}

In an attempt to make education more accessible to the wider population of South Africa, the Department of Education (DoE) has, in the last 16 years, gone to great lengths to introduce and implement a new paradigm of teaching and learning in primary and secondary school education (DoE, 2008:1; DoE, 2010:ii). Courageous attempts were made to set the foundations in the creation of an inclusive ethos so that education emerges as a secure, accepting, collaborating and stimulating community in which educators and learners are valued.

New educational and operational competencies have to be learnt to bring 'life' into teaching in the classroom, to enable learners to grasp knowledge, engage in reflective thinking, and apply knowledge in real-world situations. Researchers (Grammatikopoulos, Koustelios \& Tsigilis, 2007:634; Tshannen-Moran \& Woolfolk-Hoy, 2001:783) suggests that educator quality impacts on learners' outcomes more than any other variable throughout a learner's primary and secondary schooling years. Educators and school management teams including School Governing Bodies (SGB) are called upon to assist public schools for delivering quality education in the classroom (DoE, 2010: ii). This study focuses on operational competences that are required of secondary school educators to succeed in a classroom. It also sought to examine the relationship between secondary school educators' overall teaching satisfaction and identified competencies.

\section{Background to the study}

In an education system that strives for the equality of all cultures and languages in South Africa, an educator is often called upon to perform more than just the traditional function of knowledge transmission. The role of educators has evolved significantly. Educators who were previously required to merely transmit ready-made knowledge to learners (Christie, Butler \& Potterton, 2007:21; DoE, 2005:2; DoE, 2001: iii-iv), are now also expected to prepare learners to apply such knowledge in different spheres of life. In response to the reforms of the South African educational system, educators are now required to inculcate critical thinking skills among learners so that they are able to question, weigh evidence, identify alternative perspectives, make informed judgements and accept that the very nature of knowledge is incomplete 
(Republic of South Africa, 1995:22). This requires educators to emphasise and practise the concepts of lifelong learning, learner-centredness and process-oriented learning which have now become the mantra of educators (Halx \& Reybold, 2005:293) so that these concepts do not merely become "visionary benchmarks" (Lombard \& Grosser, 2008:562).

To perform the function of developing learners holistically and creating lifelong learners and reflective thinkers in society (Krihnaveni \& Anitha, 2007:150), educators' operational competencies need to be developed so that competence across a range of teaching roles and contexts is demonstrated (Fraser, Killen \& Nieman, 2005:230). Effective learning and productive teaching necessitates that educators stay abreast of a variety of instructional methods. They are required to continuously update their expertise in line with the curriculum (Ngwane, Wamkuru \& Odebero, 2006:354; Van Niekerk, 1997:291). Whilst learners must be exposed to critical thinking, so too must educators acquire such skills and the propensity to be self-disciplined in nurturing these skills in the spirit of enquiry (Pithers \& Soden, 2000:239). In this way learners become self-directed thinkers (Paul, 1993:33). Through the process of critical thinking and "reflective scepticism" learners too are able "assess and scrutinise knowledge prior to its consumption" (Tsui, 2002:748). Consequently, educators are expected to possess certain core operational competencies.

While the concept of 'competence' is used in a variety of contexts across sectors in South Africa, its definition becomes a significant concern within the education sector. Fraser et al. (2005:232) define competence as the skills, knowledge and abilities needed by an individual to perform in an occupation. Rainsbury, Hodges, Burchell and Lay (2001:8) perceive competencies as building blocks that must be utilised in a holistic and integrative way in any situation. In the context of this study competence is defined as the skills, knowledge and capacity to function productively and effectively in the classroom.

Several operational competencies have been identified in the literature. Educators are required to be achievement orientated and to manage performance of learners (Du Plessis, Conley \& Du Plessis, 2007:66). In this regard they are expected to compile and make various types of assessments, record marks and follow up with learners who are not performing adequately (Education Labour Relations Council (ERLC), 2003:2-3). In terms of organisational skills, educators are required to be skilled in planning, leading learners and delegating additional work and responsibilities (Bubb \& Earley, 2004:7). They also need to engage in individual/professional development, which includes undertaking further studies and training to keep abreast of new trends and developments in education. Educators also require interpersonal understanding, which includes better understanding of the learner and being a facilitator and mediator, being accountable, honest and trustworthy (RSA, 2000:47; Kruger, 1997:219; De Wet, 2004:153). They should demonstrate organisational commitment, be skilled in developing others and exhibit confidence, which includes being knowledgeable regarding the curriculum and learning programmes (ELRC, 2003:2-3). Furthermore, they are expected to have excellent written and verbal communication skills (Van Niekerk, 1997:287).

In addition to acquiring the afore-mentioned competencies, educators have a number of responsibilities that extend beyond the classroom (Du Plessis et al., 2007:66). An educator is expected to be a committed role model in the community and to play a pastoral role in providing guidance and encouragement which builds character (De Klerk \& Rens, 2003:369). During the course of teaching, an educator is also expected to encourage learners to develop a set of values and morals (DoE, 2001:27-28). Additional responsibilities of educators, as outlined by the South African Council for Educators (2000:2-3), include taking reasonable steps to ensure a safe learning environment, promoting equal opportunity for all learners, being compassionate, using appropriate language and behaviour when interacting with learners, and acting in a way that elicits respect. Educators are also expected to refrain from using their position for personal gain and to avoid placing themselves in potentially embarrassing situations, especially situations that may give rise to accusation of sexual misconduct. Furthermore, they are required to perform their professional duties with care and enthusiasm, and be vigilant to opportunities for personal development.

\section{Rationale for the study}

Education is at the heart of building a strong society, reducing inequality and narrowing the achievement gap between the previously disadvantaged and advantaged schools. In the South African context advantaged schools are those schools which have access to finance and facilities while disadvantaged schools have limited financial and physical resources. Educators are the very instrument that can be used to address this challenge and greatly improve the education of learners. Educators face the challenge of being competent in all aspects of teaching. As they enter the classroom they are faced with diverse situations which are often trying and complex (Wood, 2008:152). As a secondary school educator the primary researcher has found from personal experience that educators struggle daily to be the best they can be. It is an ongoing struggle for all educators to cope with their workload and be the best they can be. 
Jackson and Piveral (2003:347) are of the opinion that merging the heart with the mind could help the educator to survive. They use the analogy of the "the three little pigs" to describe the evolving educator. The first little pig is similar to a pre-service educator who has learned the basic knowledge required for success in the classroom. When faced with designing a classroom, this little pig builds his structure equipped with only knowledge; experience is absent. It would not take long before the winds of pressure and numerous decisions cause his structure to collapse and he flees the classroom. The second little pig builds his classroom armed with knowledge and skills. It stands a little longer, but soon the winds of pressure and numerous decisions cause his structure to slowly cave in under the pressure of time or in some cases the lack of time. What does the third little pig add that helps his classroom structure to survive and learners to perform well? Is it the 'cement' made by merging heart with mind that provides a deep understanding of one's beliefs, values, and commitments? Or is it the knowledge of the operational competencies needed to function in the education system that helps an educator to survive? Or is it the agreement of the importance of these operational competencies?

The rationale for this study was to determine educators' perceptions of the operational competencies required of them to carry out their duties successfully. This study is important to all secondary schools in South Africa (and elsewhere) as it can assist in identifying the areas that need improvement within the education system, and help the educator to be more self-sufficient and competent when teaching.

\section{Literature review}

This section looks at the concept of competency, operational competencies required in education and overall teaching satisfaction.

\subsection{The concept of competency}

The concept of competency can be traced to the distant past (Hoge, Tondora \& Marrelli, 2005 513). There is a great deal of uncertainty and debate concerning the meaning of 'competence' and how a person is deemed to be competent. It is impossible to identify a consistent hypothesis or to arrive at a definition capable of obliging and reconciling all the different ways that the term competency is used (Delamare Le Deist \& Winterton, 2005:29). A generation ago competencies were referred to as behavioural objectives (Short, 1985:3), thus the behaviour suited to accomplish a certain objective.

Today the concept of 'competency' is used in various contexts; it is not only discussed in the work environment, or in a personal context but also in the social context. Little agreement exists about what competencies are, which ones are of importance and how one should view competence (Barth, Godemann, Rieckmann \& Stoltenberg, 2007:417). The differences in meanings of the concept of competence, and the ways in which competence-based approaches have been operationalised is in its infancy and continues to be developed (Brockmann, Clarke, Méhaut \& Christopher, 2008:240).

A competency can be described as a motive, trait, a social role or the ability to use knowledge or to demonstrate certain qualities, values, skills and capabilities (Gnanam, 2000:148). In the field of human resource management competence consists of five dimensions: cognitive competence, functional competences, personal competence, ethical competences and meta-competence (Delamare Le Deist \& Winterton, 2005:35).

Cognitive competence includes knowledge of underpinning theory and concepts, as well as informal knowledge gained experientially. Functional competences are the skills or know-how in a given occupational area and the ability to demonstrate the skill. Personal competency is associated with behavioural competencies, thus the relatively enduring characteristic of a person causally related to effective or superior performance in a job. Ethical competencies include the possession of appropriate personal and professional values and the ability to make sound judgments based upon in work-related situations. Meta-competencies are concerned with the ability to cope with uncertainty, as well as with learning and reflection (Delamare Le Deist \& Winterton, 2005:35).

On the other hand, in the vocational training and educational context, competence is a combination of skills, abilities and knowledge needed to perform a task (Voorhees, 2001:8). Delamare Le Deist and Winterton (2005:39) are of the opinion that competences required of an occupation include both conceptual (cognitive, knowledge and understanding) and operational (functional, psycho-motor and applied skill) competences. It is clear that competence is not something that can be put in a box or defined by one definition; a competency can be defined through an action or it can be context based (Jirasinghe \& Lyons, 1996:18-22). The challenge is to develop a consistent and coherent typology of competence in a context (Delamare Le Deist \& Winterton, 2005:40), in this case education and specifically the operational competencies required in education by educators. In the context of this study, competence will be viewed as the combination of values, skills, abilities and knowledge that educators need to teach and ensure that learning takes place. 


\subsection{Competencies required in education}

Although the term competency is increasingly used in expert discussions about education and training, there is no clear cut definition of the term. Many nuances of meaning are attached to the term, and some competency models and approaches are much broader than others. The numerous definitions can be grouped into three main approaches: behavioural repertoires, organisational competencies and educational standards. Organisations that adopt a competency approach create a competency model specifying desirable competencies to evaluate individuals in that industry (Markus, Cooper-Thomas \& Allpress, 2005:117).

As set out in the Norms and Standards Policy (RSA, 2000:47), the concept of applied competence is used in education. Applied competence is the ability to integrate the competencies which constitute the educators' role (RSA, 2000:46). In education these competencies are specifically referred to as applied competence (RSA, 2000:44), which is the overarching term for three interrelated categories of competence in education, namely practical competence, foundational competence and reflexive competence. Practical competence is the demonstrated ability, in an authentic context, to consider a range of possibilities for action, make considered decisions about which possibility to follow, and to perform the chosen action. Foundational competence is where understanding of the knowledge and thinking underpins the action taken. Reflexive competence is the skill to integrate or connect performances and decision making with understanding and with an ability to adapt to change and unforeseen circumstances and to explain the reasons behind these adaptations.

Education is often said to aim at mastery of the topic or the body of knowledge studied. Thus, being competent is to reach a point of appropriate performance (Anderson, 2007:101-102). For secondary school educators certain core competencies are needed to function and teach in an education system and to reach the point of appropriate performance. Different qualifications may demand different levels of achievement of the operational competencies. A department or subject head will focus more on leadership and administration, whereas a level one educator may focus more on the motivation and communication with the learners in the classroom. Some competencies may appear more suitable for experienced educators than educators with little experience. The competency of planning for example will be more developed and suited to the experienced educator (RSA, 2000:46).

It is nonetheless clear that all the competencies are important as found in different studies and from different literature sources and as stated in the National Educational Policy Act of 1996 of South Africa. Competence should never be seen as something static. Educators must be well-equipped and prepared when they enter the classroom and work with learners to ensure high educational standards (Darling-Hammond, 2000:7-9). Educators ought to strive to develop their competencies continuously from their initial educational qualification until the day they retire. They may be developed in different ways, with different emphasis and at different depths, but they should be ongoing. From the literature the following operational competencies, have been identified: planning, organising, performance assessment and achievement orientation, leading, motivating, communicating, behaviour management, professional development and curriculum knowledge, interpersonal relationships and organisational commitment. A short discussion on each competency follows.

\section{Planning}

Planning is one of the main concerns of educators and remains an essential competency to guarantee that effective learning takes place (Bubb \& Earley, 2004:80). The Standards and Norms for Educators in the National Education Policy Act of 1996 clarifies that it is part of the educators' roles to design and plan lessons and learning programmes, to identify the requirements for a specific content and then select and prepare textual and visual resources for effective learning. When designing these lessons educators should also consider the objectives, content and format of the lesson when planning and preparing. For educators to ensure effective learning they need to be prepared (Van Niekerk, 1997:305).

\section{Organising}

For educators organising is the arranging and collecting of resources in such a manner as to obtain objectives agreed to in the most effective, efficient and economical way possible (Steyn, 1991:36). Assessment is the process of "identifying, gathering and interpreting information about a learner's achievement as measured against nationally agreed outcomes for a particular phase of learning" (Du Plessis, Conley \& Du Plessis, 2007:67). 


\section{Leadership}

Hoy and Miskel (2005:377) sum leadership up as a social process, both rational and emotional, in which individuals of an organisation influence the interpretation of internal and external events, the choice of the desired outcomes, power relations, motivation and orientation.

\section{Motivation}

Motivation refers to an individual's engagement, participation and persistence in particular activities (Beltman, 2009:197). It is one of the major key competencies to be a successful individual in any organisation or situation.

\section{Communication}

Labuschagne (2006:267) states that communication is the flow of information between individuals in an attempt to create understanding, influence behaviour and achieve certain objectives.

\section{Behaviour management}

Robbins (1998:72) refers to behaviour management as shaping behaviour by attempting to mould individuals by guiding their learning in graduated steps.

\section{Professional development and curriculum knowledge}

Bubb and Early (2004:4) state that continuous professional development is any activity that educators engage in which enhances their skills and knowledge and enables them to judge their approaches to the education of learners. Continuous professional development is not only important for the personal growth of educators but has a positive influence on learners.

\section{Interpersonal relationships}

Developing healthy interpersonal relationships can be defined as one's ability to understand feelings and attitudes of others, knowing how to work with people as an individual and establish cooperative work relationships (Hoy \& Miskel, 2005:382). As educators it is essential to display social or human skills naturally, unconsciously and consistently (Hoy \& Miskel, 2005:282).

\section{Organisational commitment}

In the context of education, organisational commitment would mean to exhibit confidence in developing others to have knowledge about the curriculum and learning programmes and be committed to the school as an organisation. It is vital that educators have both subject knowledge and professional knowledge of the organisation (Van Niekerk, 1997:294; ERLC, 2003:2-3).

\subsection{Teaching satisfaction}

For the purpose of this study overall teaching satisfaction refers to the job satisfaction of an educator. Fisher (1998:2) describes job satisfaction as an affective response to one's job, usually measured largely as a cognitive evaluation of job features, these being circumstances, needs, values, expectations, responsibilities and advancement in the workplace (Castillo, Conklin \& Cano, 1999:19). Thus individuals measure their job satisfaction on the basic factors that they regard as important and the difference between the amount of reward that they receive and the amount of reward they believe they should receive (Robbins, 1998:25). Spector (1997:2) surmises that job satisfaction is a global feeling about the job as a related constellation of attitudes about various aspects of the job.

\section{Problem statement}

An educator's level of teaching competence is typically judged according to a variety of positive behaviours elicited from 
learners, as well as learners' examination results (Grammatikopoulos, Koustelios \& Tsigilis, 2007:634). A deficiency of competencies, a lack of awareness by school principals and educators or the lack of implementation of all the operational competencies (reflexive, foundational and practical) required by educators, imply that a large number of elements, such as the development of a learner's values, skills and performance, are often neglected (Fraser et al., 2005:230; De Wet, 2004:154).

Operational competencies, as an identified essential ingredient in education, enhance effective teaching and enable knowledge to be conveyed using a blend of different types of techniques (Elmuti, 2004:444; Kruger \& Van Schalkwyk, 1997:7). This can only occur if educators are aware of all the operational competencies, standards and concrete qualities needed to function in the teaching environment (Fraser et al., 2005:233). Therefore, investigating educators' perceptions of what core competencies are needed to function in the teaching environment and then improving the competency levels in the areas identified may result in the enhancement of learning, overall teaching satisfaction, and the improvement of educational programmes. However, in the ever-changing education system, it is questionable as to whether schools are capable of completing the overloaded curriculum (Bubb \& Earley, 2004:81; Pitman, Bell \& Fyfe, 2000:8) while focusing on the operational competencies of the educator. With these challenges in mind the following objectives were developed. The primary objective was to identify the operational competencies perceived by educators to be important in teaching at secondary schools. The secondary objective was to investigate the relationship between secondary school educators' overall teaching satisfaction with the identified competencies

\section{Research Methodology}

In order to determine the perceptions of the educators of operational competencies an essential starting point was to identify the operational competencies needed as an educator in secondary schools. The operational competencies were identified through a literature study and the perceptions of educators of these operational competencies were further explored by using a questionnaire. A probability sampling technique in the form of simple random sampling was used to obtain data from the population. A frequency distribution table was used to summarise the data attained from the questionnaires.

\subsection{Demographic information}

The sample in this study was 211 educators of advantaged and disadvantaged secondary schools, in the Sedibeng and Fezile Dabi Districts in the Gauteng province of South Africa. It comprised eighty one male (38.6\%), and hundred and thirty female $(61.4 \%)$ respondents. One-hundred-and-nineteen $(56.4 \%)$ respondents had a Diploma or Degree, forty-nine (23.2\%) had a Post Graduate Certificate in Education, thirty-seven (17.5\%) had an Honours or B Tech qualification and only six $(2.9 \%)$ had a Masters degree. Seventy-six (36\%) respondents had between 1-5 years of service, twenty-eight (13.2\%) had between 6-10 years, twenty-one (9.9\%) had between $11-15$ years, twenty-six (12.3\%) had between $16-20$ years and sixty $(28.6 \%)$ had over 20 years of service. Table 1 exemplifies an overview of the main learning fields of the respondents. The majority of respondents' main learning fields were languages, economic and management sciences and mathematical sciences. The smallest number of respondents' was from the agricultural sciences and consumer and hospitality studies.

Table 1: Main learning fields

\begin{tabular}{|lll|}
\hline LEARNING FIELD & NO. & PERCENTAGE \\
\hline Economic and management sciences & 28 & 13.3 \\
\hline Agricultural sciences & 1 & 0.5 \\
\hline Arts and culture & 14 & 6.6 \\
\hline Life Sciences & 18 & 8.5 \\
\hline Physical Sciences & 18 & 8.5 \\
\hline Computer Sciences & 8 & 3.8 \\
\hline Mathematical Sciences & 25 & 11.8 \\
\hline Consumer and Hospitality Studies & 2 & 0.9 \\
\hline Languages & 59 & 28.0 \\
\hline Technology/Technical subjects & 20 & 9.5 \\
\hline Human and Social Studies & 8 & 3.8 \\
\hline Life Orientation & 7 & 3.3 \\
\hline Other (e.g. History and religious studies) & 3 & 1.4 \\
\hline Total & 211 & 100.0 \\
\hline
\end{tabular}


Eighty-three (39.3\%) of the respondents obtained a class average of between $51 \%$ and $60 \%$, only four respondents indicated that their class average was very low (less than 40\%), thirty-four respondents obtained a class average of between $41 \%$ and $50 \%$, sixty-one obtained a class average of between $61 \%$ and $70 \%$, and twenty respondents obtained a class average of between $71 \%$ and $80 \%$. Only nine respondents obtained a high class average of above $80 \%$.

\subsection{Factor Analysis}

The aim of factor analysis is to reveal any concealed variables that cause the manifest variables to disagree with the rest of the variables within factors. During factor extraction, the shared variance of a variable (item) is separated from its unique variance and error variance reveals an underlying factor structure. In other words, if the data contains many variables, factor analysis could be used to reduce the number of variables into interpretable dimensions. Table 2 provides an overview of the percentage of the variance explained and the eigenvalues of the factors. Five factors were extracted which resulted in $67.35 \%$ of cumulative variance.

Table 2: Percentage of variance explained and eigenvalues

\begin{tabular}{|c|c|c|c|}
\hline Components & Eigenvalues & \% of Variance & Cumulative \% \\
\hline 1 & 13.323 & 45.940 & 45.940 \\
\hline 2 & 2.348 & 8.095 & 54.035 \\
\hline 3 & 1.539 & 5.307 & 59.342 \\
\hline 4 & 1.224 & 4.222 & 63.564 \\
\hline 5 & 1.099 & 3.791 & 67.354 \\
\hline
\end{tabular}

The following factors were extracted through the factor analysis procedure; communication and behaviour management, interpersonal relationships, planning and assessment leadership skills and perseverance and organisational commitment, the factor reliability coefficients and operational definitions are provided in Table 3.

Table 3: Factor, reliability coefficient and operational definitions

\begin{tabular}{|c|c|l|l|}
\hline Factor & $\begin{array}{l}\text { Reliability } \\
\text { Coefficient }\end{array}$ & Label & Operational definitions \\
\hline 1 & .940 & $\begin{array}{l}\text { Communication } \\
\text { and behaviour } \\
\text { management }\end{array}$ & $\begin{array}{l}\text { Communication is the flow of information between individuals in an attempt } \\
\text { to create understanding, influence behaviour and achieve certain objectives. } \\
\text { Behaviour management is shaping behaviour by attempting to mould } \\
\text { individuals by guiding their learning. The primary objective of communication } \\
\text { is to shape behaviour. }\end{array}$ \\
\hline 2 & .898 & $\begin{array}{l}\text { Interpersonal } \\
\text { relationships }\end{array}$ & $\begin{array}{l}\text { Interpersonal relationships can be described as the skill that a person has to } \\
\text { understand feelings and attitudes of others, knowing how to work with } \\
\text { people as an individual and establish cooperative work relationships. }\end{array}$ \\
\hline 3 & .827 & $\begin{array}{l}\text { Planning and } \\
\text { assessment }\end{array}$ & $\begin{array}{l}\text { Planning is careful preparation, designing and interpretation of learning } \\
\text { material. Assessment is identifying, gathering and interpreting information } \\
\text { about a learner's achievement as measured against nationally agreed } \\
\text { outcomes. }\end{array}$ \\
\hline 4 & .814 & $\begin{array}{l}\text { Leadership skills } \\
\text { and perseverance }\end{array}$ & $\begin{array}{l}\text { Leadership skills and perseverance is the ability to influence people in such } \\
\text { a way that they will willingly work and strive toward achieving the goals of } \\
\text { the group. }\end{array}$ \\
\hline 5 & .803 & $\begin{array}{l}\text { Organisational } \\
\text { commitment }\end{array}$ & $\begin{array}{l}\text { Organisational commitment is the degree to which an employee identifies } \\
\text { with a particular organisation and its goals. }\end{array}$ \\
\hline
\end{tabular}

Welman et al. (2005:145) state that reliability is concerned with the findings of research and relates to the credibility of the findings through repeated measures. The reliability of the individual factors is shown in Table 3 . The five factors had an overall Cronbach alpha reliability of 0.952 . The Cronbach alpha reliability for overall teaching satisfaction was 0.905 . The resuting Cronbach alpha value demonstrates sound psychometric properties of the instrument (Nunnally, 1978). 


\subsection{Regression}

In a confirmatory approach all five variables, namely communication and behavior management, interpersonal relationships, planning and assessment, leadership skills and perseverance and organizational commitment were entered into a regression equation as independent variables. Regression analysis is a statistical technique used to investigate relationships between variables. In the study the researchers sought to establish the fundamental effect of one variable upon another (Sykes, 1993:1). Table 4 presents the multiple regression analysis of the five factors with overall teaching satisfaction.

Table 4: Regression analysis

\begin{tabular}{|l|l|l|l|}
\hline Dependant variable $\quad$ Overall teaching satisfaction & \multicolumn{3}{l|}{ sig } \\
\hline $\begin{array}{l}\text { Variable to enter } \\
\text { Independent variable }\end{array}$ & Beta & $\mathrm{t}$ & \\
\hline Factor 1:Communication and behaviour management & .191 & 1.841 & .067 \\
\hline Factor 2: Interpersonal relationships & .203 & 2.331 & .021 \\
\hline Factor 3: Planning and assessment & .066 & .794 & .428 \\
\hline Factor 4: Leadership skills and perseverance & -.094 & -.977 & .330 \\
\hline Factor 5: Organisational commitment & .302 & 4.332 & .000 \\
\hline $\mathrm{R}=0.570 \quad \mathrm{R}^{2}=0.325 \mathrm{R}^{2}=0.308$ (adjusted) $\mathrm{F}=19.711$ & & & \\
\hline
\end{tabular}

\section{Findings and discussion}

\subsection{Operational competencies perceived to be important}

The primary objective of this study was to identify the operational competencies perceived by educators to be important when teaching in secondary schools. The following factors were perceived to be important.

\section{Factor 1: Communication and behaviour management}

Factor 1, communication and behaviour management, comprised 11 variables and accounted for $45.6 \%$ of the explained variance. Educators appeared to deem communication and the management of behaviour in the classroom to be one of the most important operational competencies in education. To promote a clear sense of purpose, ensuring that the message received is the same as the message transmitted and to have the ability to influence and to generate enthusiasm through example and negotiation seems to be pertinent attributes of an educator.. This finding confirms the findings of previous studies regarding the importance of communication and behaviour management. Hoogervorst, Van der Flier and Koopman (2004:288) state that communication is more than just transmitting information. The primary objective of communication is to affect behaviour and to focus on behavioural change. This is possibly why the two different constructs of behaviour management and communication formed one construct in the factor analysis. Labuschagne (2006:267) adds that communication is the flow of information between individuals in an attempt to influence behaviour and achieve certain objectives within the classroom. If the behaviour of learners is managed, it will create an environment where the communication process can be effective and successful, ensuring that information transmitted is also understood (Robbins 1998:310). Van Niekerk (1997:287) states that teaching behaviour is about relating the desired response to particular stimuli, by creating experiences that will require particular responses. The ability of educators to manage behaviour through communication is critical when striving to achieve positive educational outcomes (Oliver \& Reschly, 2007:1).

\section{Factor 2: Interpersonal relationships}

Factor 2, interpersonal relationships, comprised 5 variables and accounted for $8 \%$ of the explained variance. The highest items loading in this factor were: "provide guidance to learners" and "establishing a relationship of openness." This implies that educators agreed that guiding learners and establishing a good relationship is of utmost importance for effective learning to take place. Interpersonal relationships were also found to be an important factor in teaching in 
previous studies. De Wet $(2004: 157)$ found that successful educators are honest, neat and reliable people who always have time for their learners. They know their learners and listen to them; they are friendly, considerate and accessible, continuously building a relationship with their learners. Educators that are real, entering into a relationship with the learners without presenting a front or façade are more likely to be effective. Educators should communicate their feelings enabling a direct personal encounter with the learners, meeting them on a person-to-person basis. Educators that are genuine in their relationships with learners, with convictions and feelings can promote better interpersonal relationships (Rogers, 1967:59).

\section{Factor 3: Planning and assessment}

Factor 3, planning and assessment, consisted of 5 variables which accounted for $5 \%$ of the explained variance. "The ability to plan so that the curriculum will be completed in a year" and "the ability to determine aims/objectives for learners" were the two items with the highest loading within this factor. This finding confirms Wood's (2008:112) finding that one of the key competencies of being a good educator lies in careful preparation, designing and interpretation of learning material and lesson planning.

Planning is a future-orientated activity that aims at drawing a blueprint about what needs to be done in an organisation (Mentz \& Pienaar, 2001:5). Before proceeding with any activity, it is necessary to determine in advance what needs to be achieved, this helps to visualise the end results and set objectives accordingly (Bates et al., 2005: 23-24). Smith and Cronje (2000:11-12) add that planning is the management function that determines an organisation's mission and goals. It involves identifying ways of attaining the goals and the resources needed to accomplish the tasks.

Assessment assists in the planning process. It is the final step within a planning process (Van Niekerk, 1997:304). The item that loaded on to this factor "the ability to assess learners work on a daily basis" indicates that it is important for an educator to assess learners daily, determining if a sufficient amount of work was done, if the work was on the correct level and if learners have the right skills to be formally assessed (Bates et al., 2005:338), the outcome will influence future planning.

Assessment is one of the main functions of a secondary school educator. It is to grade, sort and make judgements about what has been learned and identify where there are still weaknesses in the learners' understanding; marking assessments, recording an accurate account of each learner's progress and reporting the progress of each learner (Lawson, 2008:155). Assessment is the process of "identifying, gathering and interpreting information about a learner's achievement as measured against nationally agreed outcomes for a particular phase of learning" (Du Plessis et al., 2007:67).

\section{Factor 4: Leadership skills and perseverance}

Factor 4, leadership and perseverance, comprised 4 variables which accounted for $4.2 \%$ of the explained variance. Educators agreed that it is of utmost importance that deadlines within the education system are adhered to so that effective learning takes place. Perseverance was also one of the items with high loading within this factor. This supports the notion that meeting deadlines is important. As set out in the National Education Policy (RSA, 2000: 47-48) one of the seven roles of the educator is being a leader. In this role educators make decisions and manage learning in their classrooms. This competency is expected to be performed in ways which are democratic and support learners and colleagues. Potenza (2002:1) is of the opinion that implicit in this role is the need to develop key characteristics which include perseverance, originality, strong self-esteem and the ability to manage one's own frustration.

\section{Factor 5: Organisational commitment}

Factor 5 , organisational commitment, comprised 4 variables which accounted for $3.7 \%$ of the explained variance. The two items with the highest loading within this factor are:: "I accept almost any type of job assignment in order to keep working for the school" and "I talk about the school to friends as a great institute to work for" provide an indication that educators' are of the opinion that dedication to the school that they work for is a key factor to support quality education. Robbins (1998:142) describes organisational commitment as "the degree to which an employee identifies with a particular organisation and its goals, and wishes to maintain membership in the organisation." The goal of a secondary school is mainly to ensure quality education for learners (DoE, 2010:ii), thus every educator who shares this goal, is committed to the school that they works for and will accept job assignments from time to time. 


\subsection{Relationship of overall teaching satisfaction with the identified operational competencies}

The second objective of the study was to investigate the relationship between educators overall teaching satisfaction and the identified factors. The results of the regression analysis indicate that the multiple $R$ value is 0.570 , adjusted $R^{2}$ expressed as a percentage indicates that approximately $31 \%$ of the variance in overall teaching satisfaction can be accounted for by the five factors.

Factor 5 , organisational commitment had the highest contribution to teaching satisfaction ( $\beta=0.302)$. Researchers (Testa, 2001:226; Harrison \& Hubbard, 1998:609; Morrison, 1997:39; Ting, 1997:313) found in a number of studies that a strong positive relationship exists between job satisfaction and organisational commitment. Thus educators who are committed to teaching have a propensity to show a high level of teaching satisfaction.

Factor 2, interpersonal relationships made the second highest contribution to overall teaching satisfaction $(\beta=0.203)$. Marshall $(2004: 1)$ opines that in education, interpersonal relationships between learners and educators have an influence on all aspects of the school climate. Castillo et al. (1999:29) found that secondary school agricultural educators strongly agreed that interpersonal relationships have a significant effect on teaching satisfaction. Bull (2005:88) also found a positive relationship between these two factors amongst secondary schools educators in the Western Cape, South Africa.

Factor 1, communication and behaviour management, had a significant contribution to teaching satisfaction $(\beta=0.191)$. Loock (2003:32) states that communication has a significant influence on school climate and human relations, having an influence on overall teaching satisfaction and behaviour of learners. It is the key responsibility of educators as communicators, to ensure that the material is understood after the communication process has been completed. If the work that is done is understood it ensures that learning takes place, even in schools with a very diverse classroom from different backgrounds (Robbins, 1998:310). Du Plessis et al. (2007:153) state that if the correct communicative ambience is present in the classroom there should be no barriers between educators and learners, adding to the level of overall teaching satisfaction.

Factor 3, planning and assessment had a substantial contribution to teaching satisfaction $(\beta=0.066)$. When employees are included in the planning process higher levels of job satisfaction and organisational effectiveness are evident (Kim, 2002:236). Educators with higher level of teaching satisfaction show an interest in learners' achievements and performance done through assessment (Bates et al., 2005:338).

The negative Beta coefficients associated with factor 4 , Leadership skills and perseverance, $(\beta=-0.094)$ suggest that leadership skills and perseverance negatively influence teaching satisfaction of educators at secondary schools. A plausible reason for such an outcome could be attributed to the notion that school principals have been elevated to the role of managing director, similar to that of a company, whose sole responsibility is to govern and lead. This is also viewed as their domain and locus of control with very little leadership roles and flexibility given to educators who are innovative and creative (Loock, 2003:41). Stanford (2001:84) did, however, find a positive association between teaching satisfaction and perseverance.

\section{Concluding remarks}

The traditional emphasis on the acquisition and dissemination of factual knowledge is no longer appropriate to a changing society. The application of such knowledge by both educators and learners in a productive way will go a long way in preparing learners for a complex world outside the school environment. The nature of an educator's job is dynamic and requires constant updating to cope in a diverse and complex learning environment. Public secondary school educators require, in addition to their basic knowledge of educational theories and best practices, operational competencies that are necessary in establishing and promoting their instructional roles. The current study identified the following operational competencies: communication and behaviour management, interpersonal relationships, planning and assessment, leadership skills and perseverance and organisational commitment which were perceived to be important by public secondary school educators. These competencies, if well developed, may contribute not only to greater levels of productivity and overall teaching satisfaction experienced by public secondary school educators but may also result in a better learner. 


\section{References}

Anderson, K. (2007). Education and training for records professionals. Journal of Records Management, 17(2):94-106.

Barth, M.N., Godemann, J., Rieckmann, M. \& Stoltenberg, U. (2007): Developing key competencies for sustainable development in higher education. Internal Journal of Sustainability in Higher Education, 8(4):416 430.

Bates, B., Botha, M., Botha, S., Goodman, S., Ladzani, W. \& De Vries, L. (2005). Business Management. Fresh perspectives. Cape Town: Pearson Prentice Hall.

Beltman, S. (2009). Educators' motivation for continuing professional learning.Issues in Educational Research, 19(3):193-211.

Brockmann, M., Clarke, L., Méhaut, P. \& Christopher, W. (2008). Competence-based Vocational Education and Training (VET): the cases of England and France in a European perspective. Vocations and Learning, 1:227- 244.

Bull, I.H.F. (2005). The relationship between job satisfaction and organisational commitment amongst high school teachers in disadvantaged areas in the Western Cape. M.A. Mini-thesis. University of the Western Cape, Cape Town.

Bubb, S. \& Earley, P. (2004). Managing teacher workload. London: Paul Chapman Publishing.

Castillo, J.X., Conklin, E.A. \& Cano, J. (1999). Job satisfaction of Ohio agricultural education teachers. Journal of Agricultural Education, 40(2):19-27.

Christie, P., Butler, D. \& Potter, M. (2007). Report of Ministerial Committee: schools that work. Pretoria: Department of Education.

Darling-Hammond. L. (2000). Solving the dilemmas of teacher supply, demand and standards. US: Government Printer.

De Wet, C. (2004). Die beeld van die opvoeder. South African Journal of Education, 24(2):153-158.

Delamare Le Deist, F. D. \& Winterton, J. (2005). What is competence? Human Resource Development International, 8(1):27-46, Mar.Department of Education see Republic of South Africa. Department of Education.

Du Plessis, P., Conley, L. \& Du Plessis, E. (2007). Teaching and learning in South African Schools. Pretoria: Van Schaik.Education Labour Relations Council. (2003). The integrated Quality Management System. Collective agreement. No 8 of 2003. Pretoria.

Elmuti, D. (2004). Can management be taught? Journal of Management Decisions, 42(3/4):439-453.

Fisher, C.D. (1998). Mood and emotions while working - missing pieces of job satisfaction. School of Business Discussion Papers, 64:1-38.

Fraser, W.J., Killen, R. \& Nieman, M.M. (2005). Issues in competence and pre-service teacher education. Part 1. Can outcome-based programmes produce competent teachers? South African Journal of Higher Education, 19(2):229-245.

Gnanam, A. (2000). Core competency and higher education. South African Journal of Higher Education, 14(2):147-151.

Grammatikopoulos, V., Koustelios, A. \& Tsigilis, N. (2007). Applicability of the teachers' sense of efficacy scale to educators teaching innovative programmes. International Journal of Educational Management, 21(7):634-642.

Halx M.D. \& Reybold, L.E. (2005). A pedagogy of force: faculty perspectives of critical thinking capacity in undergraduate students. The Journal of Genera Education, 54:293-315

Harrison, J.K. \& Hubbard, R. (1998). Antecedents to organisational commitment among Mexican employees of a U.S. firm in Mexico. Journal of Social Psychology, 138(5):609-624.

Hoge, M. A., Tondora, J. \& Marrelli, A. F. (2005). The fundamentals of workforce competency: Implications for behavioural health. Administration and Policy in Mental Health, 32(5):509-531.

Hoogervorst, J., Van Der Flier, H. \& Koopman, P. (2004). Implicit communications in organizations: The impact of culture, structure and management practices on employee behaviour. Journal of Managerial Psychology, 19(3):288-310.

Hoy, W.K. \& Miskel, C.G. (2005). Educational administration. Theory, research and practice. New York: McGraw-Hill.

Jackson, J. \& Piveral, J.A. (2003). Management process for defining and monitoring teacher dispositions. International Journal of Educational Management, 17(7):346-356.

Jarasinghe, D. \& Lyons, G. (1996). The competent head: A job analysis of head's tasks and personality factors. London: Falmer Press.

Kim, S. (2002). Participative management and job satisfaction: lessons for management leadership.Public Administration Review, 62(2):231-241.

Krihnaveni, R. \& Anitha, J. (2007). Educators' professional characteristics. Journal of Quality Assurance in Education, 15(2):149-161.

Kruger, A.G. \& Van Schalkwyk, O.J. (1997). Classroom management. 2nd ed. Pretoria: Van Schaik Publishers.

Kruger, N. (1997). Human development and learning. In Lemmer, E.M. \& Badenhorst, D.C., (eds.). Introduction to education for South African teachers. An orientation to teaching practice. Kenwyn: Juta.

Labuschagne, M. (2006). Communication management. In Nieman, G. \& Bennett, A., (eds.). Business management. Pretoria: Van Schaik. 266-277.

Lawson, T. (2008). Assessing Students. In Drymore, S. \& Harrison, J., (eds.). Reflective teaching and learning: a guide to professional issues for beginning secondary teachers. London: Sage Publications.155-181.

Lombard, K. \& Grosser, M. (2008). Critical thinking: are the ideas of OBE failng us or are we faiing the ideals of OBE? South African Journal of Education, 28:561-579.

Loock, C. (2003). Educational leadership. Sandown: Heineman Publishers.

Markus, H., Cooper-Thomas, H. D. \&Allpress, K. N. (2005). Confounded by Competencies? An evaluation of the evolution and use of competency models," New Zealand Journal of Psychology, 34(2): 117-126.

Marshall, M.L. 2004. Examining school climate: defining factors and educational influences. [Online]. Available at:<http://education.gsu.edu/schoolsafety/>. Accessed: 07/03/2012. 
Mcevoy, A. \& Welker, R. (2000). Antisocial behavior, academic failure, and school climate. Journal of Emotional and Behavioral Disorders, 8(3):130-140, Fall.

Mentz, P.J. \& Pienaar, J. F. (2001). The educator as manager. Potchefstroom: PU for CHE.

Morrison, K.A. (1997). How franchise job satisfaction and personality affects performance, organisational commitment, franchisor relations, and intention to remain. Journal of Small Business Management, 35(3):39-68.

Ngwane, M.W., Wamkuru, D.K. \& Odebero, S.O. (2006). Total Quality management in secondary schools in Kenya: extent of practice. Journal of Quality Assurance in Education, 14(4):339-362.

Nunnally, J.C. (1978). Psychometric theory. $2^{\text {nd }}$ ed. New York : McGraw-Hill.

Oliver, R.M. \& Reschly, J.D. (2007). Effective classroom management: Teacher preparation and professional development. Washington: Vanderbilt University.

Paul, R.W. 1993. Critical thinking; what every person needs to survive in a radidy changing world. Santa Rosa, CA: Foundation for Critical Thinking

Pithers R.T \& Soden, R. (2000). Critical thinking in education: a review. Educational Research, 42:237-249.

Pitman, J.A., Bell. E.J., \& Fyfe, I.K. (2000). Assumptions and origins of competency-based assessment: new challengesfor teachers. In Board of Senior Secondary School Studies. A Paper presented at the conference of the Australian Association for Research in Education, and the New Zealand Association for Research in Education held in Melbourne in November 1999. Springhill. pp. 123.

Potenza. E. (2002). The seven roles of the teacher. The Teacher/M\&G Media, Johannesburg. February 2002. [online] Available at: http://ace.schoolnet.org.za/cd/ukzncore2a/documents/core2a.curriculum-matters.htm. Accessed on 21/09/2011.

Rainsbury, E., Hodges, D. \& Burchell, N \& LAY, M. (2001). Ranking workplace competencies: student and graduate perceptions. AsiaPacific Journal of Cooperative Education, 3(2):8-18.

Republic of South Africa (RSA). 1995. White paper on education and training. Pretoria: Government Printer

Republic of South Africa. (2000). Norms and Standards for Educators. (Act No. 27 of 1996). Government Gazette, 82:44, 4 Feb. (Regulation Gazette No. 20844).

Republic of South Africa. Department of Education. (2001). Manifesto on Values, Education and Democracy. Pretoria: Cape Argus Teach Fund for the Department of Education. Government Printer.

Republic of South Africa. Department of Education. (2005). National Curriculum Statement Grades $10-12$ (General). Pretoria: Government PrinterRepublic of South Africa. Department of Education. (2008). Access to education. Pretoria: Government Printer.

Robbins, S.P. (1998). Organisational behaviour. $8^{\text {th }}$ ed. New Jersey: Prentice Hall.

Smit, P.J. \& Cronje, G. J. de J. (2000). Management principles. 2nd ed. Kenwyn: Juta.

Spector, P.E. (1997). Job satisfaction: application, assessment, cause, and $\quad$ consequences. Thousand Oaks, CA: Sage Publications.

Steyn, T. (1991). The Teacher as a classroom manager. In Doveton, E., Farhangpour, P., Langa, V.M., Mbokazi, S.Z., Mjadu, A.Z., Nowlan, J.W., Steyn, T. \& Tait, K.J. Managerial activities of the teacher. Johannesburg: Lexicon Publishers. 29-54.

Stuart, S. (2010). In loco parentis in the public schools: abused, confused and in need of change. Legal Studies Research Paper Series, pp. $1-47$.

Sykes, A.O. (1993). The inaugural course lecture: an introduction to regression analysis. [Online]. Available at: <http://www.law.uchicago.edu/Lawecon/WkngPprs_01-25/20.Sykes.Regression.pdf>.Accessed on 25/02/2012.

Testa, M.R. (2001). Organizationalcommitment, job satisfaction, and effort in the service environment. The Journal of Psychology, 135(2):226-236.

Tshannen-Moran, M \& Woolfolk-Hoy, A. (2001). Teacher efficiency: capturing an elusive construct. Review and Educational Research, 68:789-805.

Tsui, L. (2002). Fostering critical thinking through effective pedagogy: evidence from four institutional case studies. Journal of Higher Education, 73:740-763.

Tyala, Z. (2004). School management team members' perceptions of their roles in managing Grahamstown secondary schools. M.Ed Thesis. Grahamstown: Rhodes University.

Van Niekerk, L. (1997). Teaching. In Lemmer, E.M. \& Badenhorst, D.C., (eds.).Introduction to education for South African teachers. An orientation to teaching practice. Kenwyn: Juta. pp. 279-326.

Voorhees, R.A. (2001). Competency-based learning models: A necessary future. New directions for institutional research, 110:5-13.

Welman, C., Kruger, F. \& Mitchell, B. (2005). Research methodology. 3rd ed. Cape Town: Oxford University Press.

Wood, P. (2008). Classroom management. In Drymore, R. \& Harrison, J., (eds.). Reflective teaching and learning: a guide to professional issues for beginning secondary teachers. London: Sage Publications. pp. 109-152. 